\title{
Calcium antagonism and the vasorelaxation of the rat aorta induced by rotundifolone
}

D.N. Guedes, D.F. Silva, J.M. Barbosa-Filho and I.A. Medeiros
Laboratório de Tecnologia Farmacêutica, Universidade Federal da Paraíba, João Pessoa, PB, Brasil

\begin{abstract}
Correspondence
I.A. Medeiros

Laboratório de Tecnologia

Farmacêutica

Universidade Federal da Paraíba

Caixa Postal 5009

58051-970 João Pessoa, PB

Brasil

Fax: +55-83-216-7511 or 216-7365

E-mail: isacmed@uol.com.br

Research supported by CAPES and PRONEX 98/CNPq.
\end{abstract}

Received August 12, 2003 Accepted August 17, 2004
Abstract

The vasorelaxing activity of rotundifolone (ROT), a major constituent $(63.5 \%)$ of the essential oil of Mentha $x$ villosa, was tested in male Wistar rats (300-350 g). In isolated rat aortic rings, increasing ROT concentrations $(0.3,1,10,100,300$, and $500 \mu \mathrm{g} / \mathrm{ml})$ inhibited the contractile effects of $1 \mu \mathrm{M}$ phenylephrine and of 80 or $30 \mathrm{mM} \mathrm{KCl}$ $\left(\mathrm{IC}_{50}\right.$ values, reported as means $\pm \mathrm{SEM}=184 \pm 6,185 \pm 3$ and $188 \pm$ $19 \mu \mathrm{g} / \mathrm{ml}, \mathrm{N}=6$, respectively). In aortic rings pre-contracted with 1 $\mu \mathrm{M}$ phenylephrine, the smooth muscle-relaxant activity of ROT was inhibited by removal of the vascular endothelium $\left(\mathrm{IC}_{50}\right.$ value $=235 \pm$ $7 \mu \mathrm{g} / \mathrm{ml}, \mathrm{N}=6)$. Furthermore, ROT inhibited $\left(\mathrm{pD}_{2}=6.04, \mathrm{~N}=6\right)$ the $\mathrm{CaCl}_{2}$-induced contraction in depolarizing medium in a concentration-dependent manner. In $\mathrm{Ca}^{2+}$-free solution, ROT inhibited $1 \mu \mathrm{M}$ phenylephrine-induced contraction in a concentration-dependent manner and did not modify the phasic contractile response evoked by caffeine $(20 \mathrm{mM})$. In conclusion, in the present study we have shown that ROT produces an endothelium-independent vasorelaxing effect in the rat aorta. The results further indicated that in the rat aorta ROT is able to induce vasorelaxation, at least in part, by inhibiting both: a) voltage-dependent $\mathrm{Ca}^{2}$ channels, and b) intracellular $\mathrm{Ca}^{2+}$ release selectively due to inositol 1,4,5-triphosphate activation. Additional studies are required to elucidate the mechanisms underlying ROTinduced relaxation.

\section{Introduction}

The plant Mentha $x$ villosa Hudson (Lamiaceae) or "hortelã-da-folha-miúda" is an herb extensively cultivated in northeastern Brazil, where it is popular for its antiparasitic and tranquilizing effects as well as the relief of stomach disorders and menstrual pain (1). The widespread use of this plant in local phytotherapeutic industries has stimulated pharmacological studies on its essential oil (EOMV) and chemical constituents.
Key words

- $\mathrm{Ca}^{2+}$ mobilization

- Rat aortic rings

- Rotundifolone

- Vasorelaxation

- Mentha x villosa
Rotundifolone (ROT), an oxygenated monoterpene (Figure 1), is an important chemical constituent of the essential oil of many Mentha species (Mentha rotundifolia, M. suaveolens, M. spicata L., M. longifolia, and $M . x$ villosa). It has been reported that ROT is the major constituent $(63.5 \%)$ of the EOMV, which also contains 23 other minor constituents (2).

In our preliminary pharmacological studies, EOMV presented hypotensive and bradycardic effects in non-anesthetized normoten- 
sive rats (3). Furthermore, we reported that in rats, the hypotensive effect of EOMV was probably due to peripheral vasodilatation partly secondary to nitric oxide release by the vascular endothelium and to its inhibitory action on the $\mathrm{Ca}^{2+}$ influx into smooth muscle cells (3). Using a combined in vivo and in vitro approach, we demonstrated that ROT induced significant and dose-dependent hypotension and bradycardia in non-anesthetized normotensive rats (4). We suggested that the hypotensive action of ROT could be due in part to a decrease in heart rate and peripheral vascular resistance, probably due to non-selective muscarinic receptor stimulation (4). Furthermore, Sousa et al. (5) reported that ROT had a relaxant effect on guinea pig ileum, apparently mediated by an intracellular effect on $\mathrm{Ca}^{2+}$ mobilization.

The aim of the present study was to characterize the endothelium-independent mechanisms involved in the smooth muscle relaxation of rat aorta produced by ROT, specifically regarding the action of $\mathrm{Ca}^{2+}$ (influx and/or release from intracellular stores).

\section{Material and Methods}

\section{Plant material}

Mentha $x$ villosa leaves were collected in

Figure 1. Chemical structure of rotundifolone (1,2-epoxy-pmenth-4(8)-en-3-one).
João Pessoa, PB, Brazil, in September 1992 and authenticated by Dr. Harley of the Royal Botanic Gardens, Kew, England. A voucher specimen was deposited in the Prisco Bezerra Herbarium of the Federal University of Ceará (No. 14996).

\section{Preparation of essential oil}

Mentha $x$ villosa fresh leaves $(10 \mathrm{~kg})$ were subjected to steam distillation for $8 \mathrm{~h}$. The oil, obtained $(0.1 \%)$ in the usual way (6), was dried over $\mathrm{Na}_{2} \mathrm{SO}_{4}$, stored at $4^{\circ} \mathrm{C}$ and then analyzed by GC/MS using a Hewlett Packard apparatus (GC chromatograph model 5890 and mass spectrometer model 5988A; Palo Alto, CA, USA). The major constituent $(63.5 \%)$ of the oil was ROT (Figure 1).

\section{Isolation and identification of rotundifolone}

ROT was isolated and identified by the methods described by Almeida et al. (2). EOMV was subjected to thin-layer chromatography (Si-gel $\mathrm{PF}_{254}, 40 \times 20 \mathrm{~cm}$ plates; Merck, Darmstadt, Germany). The plates were developed three times with n-hexane as solvent. Two well-separated bands were visible under a UV lamp. The bands were cut and extracted in the usual way using $\mathrm{CH}_{2} \mathrm{Cl}_{2}$ and ROT was obtained from the slower moving band with $99.9 \%$ spectroscopical purity. ROT is a light yellow oil; $[\alpha] \mathrm{D}^{27}=+148^{\circ}$ (c 0.3, $\mathrm{CHCl}_{3}$ ); $\mathrm{MS} \mathrm{m} / z$ (rel. int. \%): $166\left(\mathrm{M}^{+}\right.$, 23), 138 (100), 137 (33), 109 (28), 95 (19), 79 (30), 67 (72), 41 (16); ${ }^{1} \mathrm{H}-\mathrm{NMR}$ (200 $\mathrm{MHz}, \mathrm{CDCl}_{3}$ ): $\delta 1.45$ (3H, s, H-10), 1.77 (3H, s, H-8), 2.06 (3H, s, H-9), 1.80-2.14 (2H, $m, \mathrm{H}-6), 2.30-2.55$ (2H, $m, \mathrm{H}-5), 3.21$ $(1 \mathrm{H}, s, \mathrm{H}-2) ;{ }^{13} \mathrm{C}-\mathrm{NMR}\left(50 \mathrm{MHz}, \mathrm{CDCl}_{3}\right): \delta$ 21.5 (C-10), 22.7 (C-5,8), 27.8 (C-6), 63.0 (C-2), 63.1 (C-1), 127.4 (C-4), 147.0 (C-7), 196.1 (C-3). Carbon resonances were assigned by distortionless enhancement by polarization transfer and heteronuclear correlation experiments (7). 


\section{Animals}

Male Wistar rats (300-350 g) were used for all experiments. Animals were housed under conditions of controlled temperature $\left(21 \pm 1^{\circ} \mathrm{C}\right)$ and exposed to a daily 12 -h lightdark cycle.

\section{Studies using isolated rat aortic rings}

Rat aortic rings (2-4 mm) were obtained free from connective tissue and fat and suspended on platinum hooks for isometric tension recordings in Krebs-Henseleit solution, maintained at $37^{\circ} \mathrm{C}$ and gassed with a mixture of $95 \% \mathrm{O}_{2}$ and $5 \% \mathrm{CO}_{2}$. The rings were allowed to equilibrate for $1 \mathrm{~h}$ under a resting tension of $1 \mathrm{~g}$. During this time, the bathing medium was changed every $15 \mathrm{~min}$ to protect against interfering metabolites (8). Rings without endothelium were obtained by gently rubbing the intimal surface of the vessel.

\section{Solutions}

The composition of the Krebs-Henseleit solution, $\mathrm{pH} 7.4$, used for isolated tissues was: $118.0 \mathrm{mM} \mathrm{NaCl}, 4.7 \mathrm{mM} \mathrm{KCl}, 25.0$ $\mathrm{mM} \mathrm{NaHCO} 3,2.5 \mathrm{mM} \mathrm{CaCl} \mathrm{Cl}_{2} .2 \mathrm{H}_{2} \mathrm{O}, 11.1$ $\mathrm{mM}$ glucose, $1.2 \mathrm{mM} \mathrm{K \textrm {KH } _ { 2 }} \mathrm{PO}_{4}$, and $1.2 \mathrm{mM}$ $\mathrm{MgSO}_{4} \cdot 7 \mathrm{H}_{2} \mathrm{O}$. The composition of the solution with $80 \mathrm{mM} \mathrm{KCl}$ was $57.0 \mathrm{mM} \mathrm{NaCl}$, $80.0 \mathrm{mM} \mathrm{KCl}, 23.1 \mathrm{mM} \mathrm{NaHCO}, 2.5 \mathrm{mM}$ $\mathrm{CaCl}_{2} \cdot 2 \mathrm{H}_{2} \mathrm{O}, 11.1 \mathrm{mM}$ glucose, $1.1 \mathrm{mM}$ $\mathrm{KH}_{2} \mathrm{PO}_{4}$, and $5.7 \mathrm{mM} \mathrm{MgSO} 4.7 \mathrm{H}_{2} \mathrm{O}$, and the composition of the solution with $30 \mathrm{mM}$ $\mathrm{KCl}$ was $87.3 \mathrm{mM} \mathrm{NaCl}, 30.0 \mathrm{mM} \mathrm{KCl}, 23.1$ $\mathrm{mM} \mathrm{NaHCO} 3,2.5 \mathrm{mM} \mathrm{CaCl} 2.2 \mathrm{H}_{2} \mathrm{O}, 11.1$ $\mathrm{mM}$ glucose, $1.1 \mathrm{mM} \mathrm{KH}_{2} \mathrm{PO}_{4}$, and $5.7 \mathrm{mM}$ $\mathrm{MgSO}_{4} \cdot 7 \mathrm{H}_{2} \mathrm{O}$. Isosmotic $65.4 \mathrm{mM} \mathrm{K}^{+}$solution was prepared by replacing $60 \mathrm{mM} \mathrm{NaCl}$ in the normal solution with equimolar $\mathrm{KCl}$. The $\mathrm{Ca}^{2+}$-free solution was prepared by omitting $\mathrm{CaCl}_{2}$ and adding $1 \mathrm{mM}$ ethyleneglycol bis ( $B$-aminoethylether)-N,N,N', N' tetraacetic acid. The nominally $\mathrm{Ca}^{2+}$-free solutions were prepared by omitting only
$\mathrm{CaCl}_{2}$. Modified Krebs-Henseleit solution (high-K ${ }^{+}$nominally $\mathrm{Ca}^{2+}$-fre solution) contained $72.7 \mathrm{mM} \mathrm{NaCl}, 50.0 \mathrm{mM} \mathrm{KCl}, 25.0$ $\mathrm{mM} \mathrm{NaHCO} 3,11.1 \mathrm{mM}$ glucose, $1.2 \mathrm{mM}$ $\mathrm{KH}_{2} \mathrm{PO}_{4}$, and $1.2 \mathrm{mM} \mathrm{MgSO} 4.7 \mathrm{H}_{2} \mathrm{O}$.

\section{Drugs}

The drugs used were phenylephrine, caffeine and acetylcholine hydrochloride (all from Sigma, St. Louis, MO, USA). For the experiments, ROT was dissolved in $0.01 \%$ cremophor (a nonionic solubilizer and emulsifier manufactured by reacting castor oil with ethylene oxide in a molar ratio of 1 to 35) plus distilled water. All the stock solutions were prepared in distilled water and kept at $4^{\circ} \mathrm{C}$.

\section{Experimental protocols}

Effects of ROT on isolated rat aortic rings. Different ROT concentrations $(0.3,1$, $10,100,300$, and $500 \mu \mathrm{g} / \mathrm{ml}$ ) were added cumulatively to isolated aortic preparations pre-contracted with either phenylephrine (1 $\mu \mathrm{M})$ or $\mathrm{KCl}(80$ or $30 \mathrm{mM})$. In some experiments, phenylephrine or $\mathrm{KCl}$ was added to the tissues and left for at least $2 \mathrm{~h}$ to observe whether the tension was maintained during this period. The relaxation was measured by comparing the developed tension before and after the addition of ROT. IC $_{50}$ values were calculated from linear regression lines fitted to individual curves (9). The vehicle (cremophor at a final concentration of $0.01 \%$ in the organ bath) given alone was completely devoid of effect on the concentration-response curves.

Influence of vascular endothelium on the relaxing response of ROT against phenylephrine-induced contractions. In this experiment, phenylephrine-induced sustained contractions were obtained in denuded endothelium rings. Rings without endothelium were obtained by gently rubbing the intimal surface of the vessel. After a third phenyleph- 
Figure 2. Effect of increasing concentrations of rotundifolone (ROT) on $1 \mu \mathrm{M}$ phenylephrineor 80 or $30 \mathrm{mM} \mathrm{KCl-induced} \mathrm{con-}$ tractions of isolated rat aortic rings. The concentrations of ROT used were $0,0.3,1.0,10$, 100,300 , and $500 \mu \mathrm{g} / \mathrm{ml}$. Data are reported as means \pm SEM for 6 preparations. The $\mathrm{IC}_{50}$ values are given in the figure. ${ }^{*} \mathrm{P}<$ 0.05 compared to phenylephrine (Phe; control; unpaired Student $t$-test). rine contraction, ROT $(0.3,1,10,100,300$, and $500 \mu \mathrm{g} / \mathrm{ml}$ ) was cumulatively added to the preparations. The effectiveness of endothelium removal was determined by the loss of the relaxing response of the preparations to $1 \mu \mathrm{M}$ acetylcholine.

Effect of ROT on voltage-dependent $\mathrm{Ca}^{2+}$ channels. The preparations were bathed for 15 min in nominally $\mathrm{Ca}^{2+}$-free KrebsHenseleit solution, and then exposed for an additional $15 \mathrm{~min}$ to a high- $\mathrm{K}^{+}(65.4 \mathrm{mM})$ nominally $\mathrm{Ca}^{2+}$-free solution (depolarizing medium) $(10,11)$. Soon afterwards, two cumulative concentration-response curves for $\mathrm{CaCl}_{2}$ were obtained. ROT $(10,100$ and 300 $\mu \mathrm{g} / \mathrm{ml}$ ) was added to the preparations for 15 min, and then a third cumulative concentration-response curve for $\mathrm{CaCl}_{2}$ was obtained. The maximal contraction obtained with the control concentration-response curve for $\mathrm{CaCl}_{2}$ was taken as $100 \%$, and all contractions were calculated as a function of this value. Each preparation was exposed to only one ROT concentration.

Influence of ROT on phenylephrine- or caffeine-induced transient contractions. The effect of ROT $(10,100,300$, and $500 \mu \mathrm{g} / \mathrm{ml})$ on intracellular calcium stores sensitive to phenylephrine or caffeine was investigated using the protocol described by Karaki and Weiss (12). After the stabilization period, the tissues were exposed to a $65.4 \mathrm{mM} \mathrm{K}^{+}$ solution for 3 min and washed with $\mathrm{Ca}^{2+}$ -

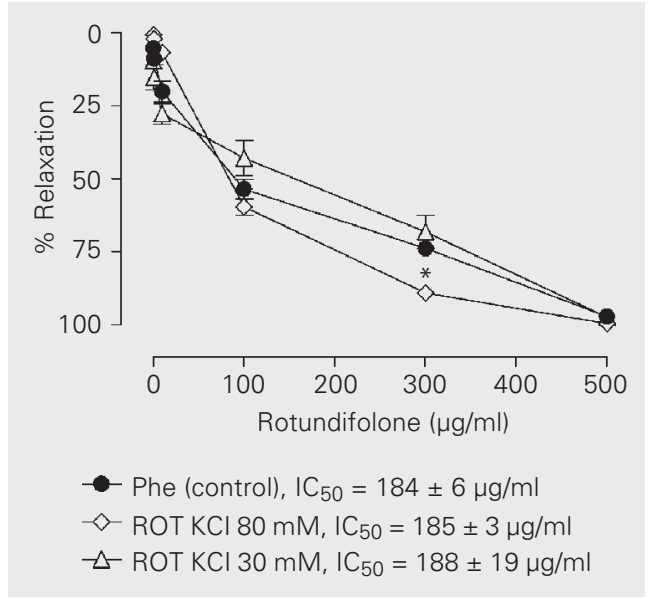

free solution, with $10 \mu \mathrm{M}$ phenylephrine or $20 \mathrm{mM}$ caffeine being added thereafter. After washing the tissues with normal KrebsHenseleit solution, high potassium solution $\left(65.4 \mathrm{mM} \mathrm{K}^{+}\right)$was added for $3 \mathrm{~min}\left(\mathrm{Ca}^{2+}\right.$ loading). The preparations were washed with $\mathrm{Ca}^{2+}$-free solution followed again by the administration of phenylephrine or caffeine. This procedure was repeated until two similar transient contractions to the agonists were obtained. The experiment was then repeated, with ROT added 2 min before the administration of phenylephrine or caffeine. Each preparation was exposed to only one concentration of ROT. The temperature was decreased to $25^{\circ} \mathrm{C}$ in the protocols in which caffeine was used as an agonist (13).

\section{Statistical analysis}

Data are reported as means \pm SEM. Statistical analysis was performed by one-way analysis of variance for repeated measures. Unpaired Student $t$-tests were also used when appropriate. Linear regressions were performed by the least squares method using GraphPad Prism $^{\mathrm{TM}}$ software, version 3.02 (GraphPad Software, Inc., San Diego, CA, USA). Schild plots were analyzed by linear regression. Antagonism was judged to be non-competitive when the slope of the Schild plot was significantly different from the unit and depression of maximum response was observed.

\section{Results}

As illustrated in Figure 2, in isolated rat aortic rings, ROT $(0.3,1,10,100,300$, and $500 \mu \mathrm{g} / \mathrm{ml})$ antagonized in a significant $(\mathrm{P}<$ $0.05)$ and concentration-dependent manner the contractions induced by phenylephrine $(1 \mu \mathrm{M})$ or $\mathrm{KCl}(80$ or $30 \mathrm{mM})\left(\mathrm{IC}_{50}\right.$ values $=$ $184 \pm 6,185 \pm 3$ and $188 \pm 19 \mu \mathrm{g} / \mathrm{ml}$, respectively). The maximal relaxing response was obtained with $500 \mu \mathrm{g} / \mathrm{ml}$ and did not differ significantly from that induced by 1000 
$\mu \mathrm{g} / \mathrm{ml}$.

The experiments also demonstrated that an important part of the vasorelaxing response induced by ROT was endothelium dependent, since after endothelium removal the relaxant responses induced by ROT were significantly $(\mathrm{P}<0.05)$ reduced (Figure 3$)$.

Figure 4 shows the mean cumulative concentration-response curves for $\mathrm{CaCl}_{2}$ alone and in the presence of different concentrations of ROT (10, 100 and $300 \mu \mathrm{g} / \mathrm{ml})$. ROT produced a non-parallel and concentrationdependent rightward shift of the concentration-response curves for $\mathrm{CaCl}_{2}$, significantly reducing the maximal response. The $\mathrm{pD}_{2}$ and Shild's plot slope values were 6.04 and 0.0000153 , respectively, indicating a noncompetitive blockade.

Figure 5 shows the transient contraction induced by $1 \mu \mathrm{M}$ phenylephrine or $20 \mathrm{mM}$ caffeine in a $\mathrm{Ca}^{2+}$-free solution. The results demonstrated that transient contractions induced by $1 \mu \mathrm{M}$ phenylephrine were significantly antagonized by ROT in a concentration-dependent manner $(10,100,300$, and $500 \mu \mathrm{g} / \mathrm{ml})$. However, the contractions induced by caffeine were not inhibited by ROT, even at the highest concentration $(500 \mu \mathrm{g} /$ $\mathrm{ml})$.

\section{Discussion}

In present study, we investigated the effects of ROT on vascular smooth muscle, and the major finding was that ROT-induced vasodilation of the rat aorta may be secondary to an inhibitory effect on $\mathrm{Ca}^{2+}$ influx through voltage-dependent $\mathrm{Ca}^{2+}$ channels and to selective inhibition of intracellular $\mathrm{Ca}^{2+}$ from norepinephrine-sensitive stores in smooth muscle cells.

A vasorelaxing effect was reported for ROT in guinea pig aorta (5) and in rat aorta (4), and in the present study we evaluated the activity of ROT in the rat aorta. We found that ROT was able to inhibit in a concentration-dependent manner phenylephrine- and
$\mathrm{KCl}$-induced contractions with a similar potency. In phenylephrine-induced contractions in aortic preparations in which the endothelium was removed mechanically, ROT-induced smooth muscle relaxation was signifi-
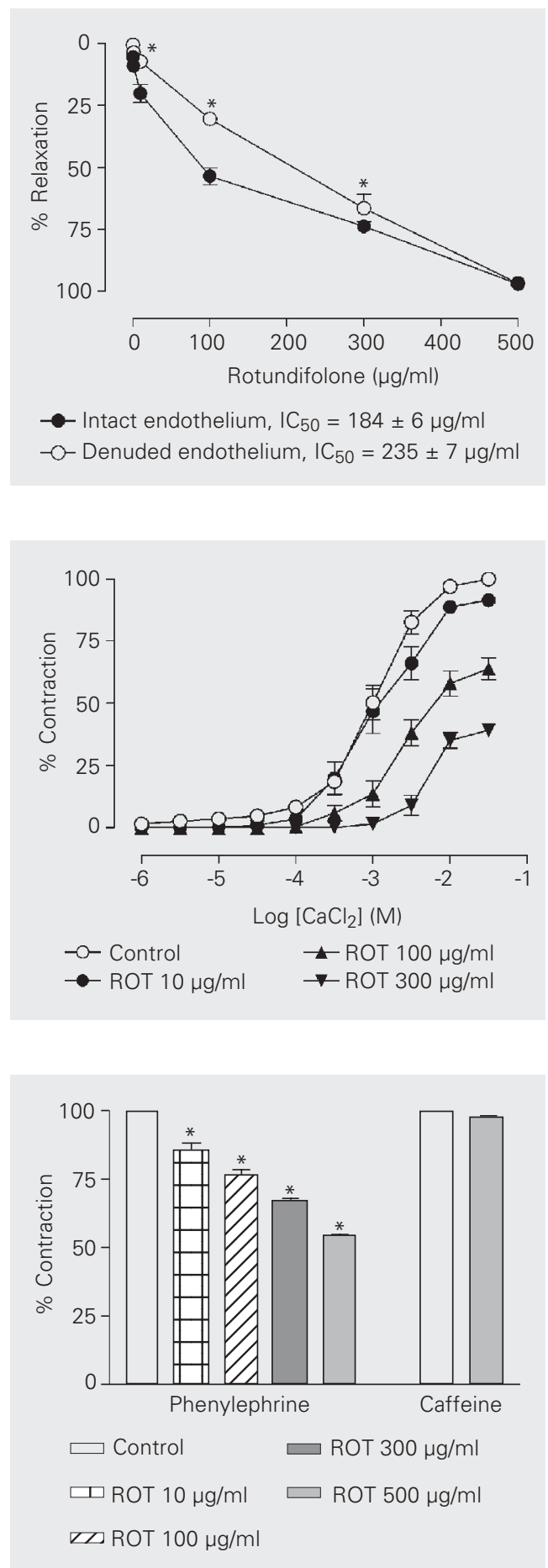

Figure 3. Effect of intact and denuded endothelium on the action of rotundifolone (ROT) on $1 \mu \mathrm{M}$ phenylephrine-induced contractions of aortic rings. The concentrations of ROT were 0 , $0.3,1.0,10,100,300$, and 500 $\mu \mathrm{g} / \mathrm{ml}$. Data are reported as means \pm SEM for 6 preparations. The $\mathrm{IC}_{50}$ values are given in the figure. ${ }^{*} P<0.05 \mathrm{com}-$ pared to intact endothelium (unpaired Student $t$-test).

Figure 4. Effect of the concentrations of rotundifolone (ROT) on the cumulative concentration-response curves for $\mathrm{CaCl}_{2}$ in nominally $\mathrm{Ca}^{2+}$-free depolarizing medium of isolated rat aortic rings. The concentrations of ROT were 10, 100 and $300 \mu \mathrm{g} /$ $\mathrm{ml}$. Data are reported as means \pm SEM for 6 preparations.

Figure 5. Effect of increasing concentrations of rotundifolone (ROT) on $1 \mu \mathrm{M}$ phenylephrineor $20 \mathrm{mM}$ caffeine-induced transient contractions in $\mathrm{Ca}^{2+}{ }_{-}$-free medium of isolated rat aortic rings. The concentrations of ROT were 10, 100, 300, and 500 $\mu \mathrm{g} / \mathrm{ml}$. Data are reported as means \pm SEM for 6 preparations. ${ }^{*} \mathrm{P}<0.05$ compared to control (unpaired Student $t$-test). 
cantly reduced, but not completely abolished. Recently (4), we showed that part of the relaxant effect of ROT on isolated rat aortic rings could be due to the stimulation of endothelial $\mathrm{M}_{3}$-receptors and consequently to the release of endothelium-derived relaxing factors, mainly nitric oxide. The smooth muscle-relaxant activity of ROT was inhibited, but not completely abolished by removal of the vascular endothelium, by a muscarinic non-selective antagonist (atropine), by a competitive inhibitor of NOsynthase (L-NAME) or by a cyclooxygenase inhibitor (indomethacin) (4). These results indicate that the vasorelaxing effect of ROT on the rat aorta seems to be due in part to an endothelium-independent mechanism.

It has been reported that phenylephrineinduced vasoconstriction is mediated by the stimulation of G-protein coupled to $\alpha$-adrenoceptors (14), whereas $\mathrm{KCl}$ induces smooth muscle contraction through the activation of voltage-dependent calcium channels and subsequent release of calcium from the sarcoplasmic reticulum $(15,16)$. In both cases, the major resulting effect is an increase in intracellular calcium concentration through calcium entry. We therefore suggest that the vasorelaxing activity observed in the present study is partially due to a mechanism linked to the inhibition of $\mathrm{Ca}^{2+}$ influx through voltage-dependent $\mathrm{Ca}^{2+}$ channels and/or to an inhibitory effect on intracellular $\mathrm{Ca}^{2+}$ release. This hypothesis is well acceptable, since ROT inhibited in a concentration-dependent manner $\mathrm{CaCl}_{2}$-induced contractions in the aortic rings in the depolarizing medium. Whether ROT inhibits the $\mathrm{Ca}^{2+}$ influx across the membrane by acting directly on voltage-dependent $\mathrm{Ca}^{2+}$ channels or indirectly by blocking protein kinase $\mathrm{C}$, or opening potassium channels, are some questions that need to be answered.

Phenylephrine induces transient contractions in smooth muscle in $\mathrm{Ca}^{2+}$-free solution, a fact attributable to release of $\mathrm{Ca}^{2+}$ from intracellular stock sites (12). The transient contractions induced by phenylephrine were inhibited by ROT in a concentration-dependent manner. It has been reported that phenylephrine-induced $\mathrm{Ca}^{2+}$ release is attributable to receptor-mediated formation of inositol 1,4,5-triphosphate, whereas caffeine-induced $\mathrm{Ca}^{2+}$ release is due to a $\mathrm{Ca}^{2+}$-induced $\mathrm{Ca}^{2+}$ release mechanism (12). The fact that the same concentrations of ROT that inhibit phenylephrine-induced contractions did not inhibit the caffeine contractions suggests that the inhibitory effect of ROT on phenylephrine cannot be attributable to direct inhibition of the contractile elements of the smooth muscle machinery. Thus, ROT may inhibit in a relatively selective manner the $\mathrm{Ca}^{2+}$ release from 1,4,5-triphosphate intracellular stores in the rat aorta. Nevertheless, in the present study the influence of ROT on another step of the cascade of events that lead to smooth muscle contraction could not be ruled out and further studies are required to confirm the direct relationship between the actions of ROT and the intracellular $\mathrm{Ca}^{2+}$ levels in smooth muscle.

\section{Acknowledgments}

The authors wish to express their sincere thanks to José Crispim Duarte and Raimundo Nonato da Silva for technical assistance.

\section{References}

1. Alencastro FMMR, Scatone Z, Prisco JT \& Laboriau LFG (1965). Contribuição para uma bibliografia do gênero Mentha L. Associação Brasileira de Pesquisa de Plantas Aromáticas. Óleos Essenciais, Campinas, SP, Brazil, 354.

2. Almeida RN, Hiruma CA \& Barbosa-Filho JM (1996). Analgesic effect of rotundifolone in rodents. Fitoterapia, 67: 334-338.
3. Guedes DN, Silva DF, Barbosa-Filho JM \& Medeiros IA (2004). Endothelium-dependent hypotensive and vasorelaxing effects of the essential oil from aerial parts of Mentha $x$ villosa in rats. Phytomedicine, 11: 490-497

4. Guedes DN, Silva DF, Barbosa-Filho JM \& Medeiros IA (2002). Muscarinic agonist properties involved in the hypotensive and 
vasorelaxing responses of rotundifolone in rats. Planta Medica, 68: 700-704.

5. Sousa PJC, Magalhães PJC, Oliveira VS, Lima CC \& Leal-Cardoso $\mathrm{JH}$ (1997). Effects of piperitenone oxide on the intestinal muscle of the guinea pig. Brazilian Journal of Medical and Biological Research, 30: 787-791.

6. Craveiro AA \& De Queiroz DC (1993). Óleos essenciais e química fina. Química Nova, 16: 224-228.

7. Silverstein RM \& Webster FX (2000). Indentificação Espectométrica de Compostos Orgânicos. 6th edn. Livros Técnicos Científicos Editora S.A., Rio de Janeiro, Brazil, 6: 222-223.

8. Altura BM \& Altura BT (1970). Differential effects of substrate depletion on drug-induced contractions of rabbit aorta. American Journal of Physiology, 219: 1698-1705.

9. Lichfield JT \& Wilcoxon FA (1949). A simplified method of evaluating dose-effect experiments. Journal of Pharmacology and Experimental Therapeutics, 96: 99-113.

10. Goodfraind T, Miller R \& Wibo M (1986). Calcium antagonism and calcium entry blockade. Pharmacological Reviews, 38: 321-345.
11. Weiss GB (1981). Site of action of calcium antagonist in vascular smooth muscle. In: Weiss GB (Editor), New Perspectives on Calcium Antagonists. American Physiological Society, Bethesda, MD, USA, 47-57.

12. Karaki H \& Weiss GB (1988). Calcium release in smooth muscle. Life Sciences, 42: 111-122.

13. Susana C, Maria DI, Marinez S, Eliorraga M \& Pilar O (1997). Relationships between structure and vascular activity in a series of benzylisoquinolines. British Journal of Pharmacology, 122: 409-416.

14. Pérez-Viscaíno F, Cogolludo AL, Villamor E \& Tamargo J (1998). Role of $\mathrm{K}^{+}$channel opening and stimulation of cyclic GMP in the vasorelaxant effects of nicorandil in isolated piglet pulmonary and mesenteric arteries: relative efficacy and interactions between both pathways. British Journal of Pharmacology, 123: 847-854.

15. Gurney AM (1994). Mechanisms of drugs-induced vasodilatation. Journal of Pharmacy and Pharmacology, 46: 242-251.

16. Nasa $Y$, Ichiara K, Yoshida R \& Abiko $Y$ (1992). Positive inotropic and negative chronotopic effects of (-)-Cis-Diltiazem in rat isolated atria. British Journal of Pharmacology, 105: 696-702. 